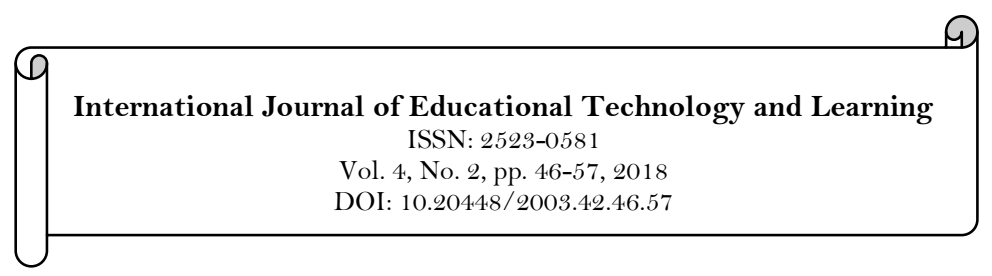

Cupdates

\title{
Constraints Hindering Adoption of ICT in Government Secondary Schools in Tanzania: The Case of Hanang District
}

\author{
Kunda Humphrey Kweka ${ }^{2}$ \\ Placidius Ndibalema ${ }^{2}$ \\ ${ }^{1}$ Nangwa Secondary School, Katesh, Manyara Tanzania. \\ Email:kwekakinda@yahoo.com \\ ${ }^{2}$ Department of Educational Foundations and Continuing Education, The University of Dodoma, Tanzania
}

\begin{tabular}{|c|c|}
\hline Abstract & \\
\hline $\begin{array}{l}\text { This paper addresses teachers' skills on ICT Integration in teaching } \\
\text { and learning and constraints that hinder the adoption in Government } \\
\text { owned secondary schools. The study employed a cross-section } \\
\text { research design which guided the collection of both quantitative and } \\
\text { qualitative data. Simple random sampling was employed in the } \\
\text { selection of participants of which data were collected from } 75 \text { teachers } \\
\text { in government secondary schools, } 15 \text { Heads of Schools, } 1 \text { DEO and } 3 \\
\text { Quality Assurers. Questionnaires and interviews were used to obtain } \\
\text { data. Qualitative data were analysed through content analysis while } \\
\text { descriptive statistics was used to analyse quantitative data with the aid } \\
\text { of SPSS version } 21 \text {. The findings revealed that, most of the secondary } \\
\text { school teachers had minimal skills of integrating ICT in teaching and } \\
\text { learning due to different challenges such as lack of ICT facilities, } \\
\text { inadequate computer labs in schools, and inadequate pre-service and } \\
\text { in-service teachers training. Finally, the paper recommends a holistic } \\
\text { approach in harmonising the curriculum requirements and the ICT } \\
\text { policy strategies so as to create awareness among teachers, thus } \\
\text { develop the required ICT pedagogical skills. }\end{array}$ & $\begin{array}{l}\text { Licensed: } \\
\text { This work is licensed under a } \\
\text { Creative Commons Attribution } \\
\text { 4.0 License. } \\
\text { Publisher: } \\
\text { Scientific Publishing Institute }\end{array}$ \\
\hline
\end{tabular}

\section{Background to the Research Problem}

The world is experiencing rapid changes which cause the explosion of new emerging technologies. These changes are happening all over the world, including developing countries like Tanzania. In this sense, the developing countries should make efforts to improve the quality of education by strengthening the implementation of classroom instructional process in order to embrace the changes realistically. Generally, technology can make our lives easier and simplified. It is believed that, ICT is among the essential technologies useful in enhancing readiness in teaching and learning process at secondary level education. Felvégi and Matthew (2012) proposed that, the Internet with shared global resources has brought a more flexible and dynamic learning environment beyond the traditional book-teacher model which regarded classrooms as the only dominant environment for formal education.

In the context of teaching and learning, ICT can facilitate tasks and improve teachers' performance in creating effective teaching and learning activities. It promotes, strengthen and enhance skills of ICT which should be used in combination with other teaching methods. Although ICT seems to be beneficial in teaching and learning, many secondary school teachers are not willing to adopt its use in teaching and learning due to a number reasons. Cakir and Yildirim (2013) in Turkey report several factors affecting teachers' performance in using ICT including difficulties in maintaining up-to-date technology, poorly equipped IT classrooms, insufficient computers in the class and outdated curricula.

Raman and Yamat (2013) in Malaysia indicated that, lack of teachers' autonomy, and lack of knowledge to evaluate the use and role of ICT in teaching and learning are the prominent factors hindering teachers' confidence in using ICT in the classroom. They also indicated that, lack of policy framework, inadequate infrastructure, high cost and inadequate in-service training on ICT integration in education is a greater challenge for teachers to integrate ICT in teaching and learning. Moreover, Copriady (2015) affirms that, the 
most significant challenges faced by teachers are in handling a model shift towards the ever changing methods of teaching and learning and how to use computers and ICT as an alternative approach. Although some teachers seem to be reluctant to adopt ICT in their teaching and learning process, they should be aware of its importance and make an effort to update their professional skills.

Likewise, in Africa various scholars came out with different perception regarding teachers' adoption of ICT as a pedagogical tool in teaching and learning. For instance, Mingaine (2013) in Kenya asserts that, inadequate supply of qualified ICT teachers was found to be a major challenge in the process of implementing ICT in schools. Most schools did not have enough staff competent in ICT and therefore were not able to effectively integrate ICT in teaching and learning. Also, some of the education stakeholders do not prioritize ICT in secondary school in Kenya. Salisu and Muhammad (2016), assert that, in Nigeria there is a shortage of qualified teachers who can use ICT in teaching and learning. The demand for ICT learning has been tremendous and the number of teachers who are trained to teach using ICT cannot meet the demand. Also, most schools are suffering from lack of internet and slow connectivity to the extent that teachers and students cannot access the World Wide Web, due to high connectivity costs (ibid). In this condition teacher's adoption in using ICT to improve teaching and learning in secondary schools become very low.

Also, Adelabu and Adu (2015) reported that, teachers need to have good knowledge of ICT so as to guide the students and moderate learning activities properly. For example, learners in schools have the habit of using their break time judiciously to form notes and solve academic tasks using their phones, tablets, i-pad etc. This in itself promotes creativity among the learners, but the management of school is less cumbersome with the use of ICT in teaching and learning Adelabu and Adu (2015). The setback of these arguments was that ICT devices are not allowed to be used by the students in schools. This is due to the fact that, some teachers have negative attitudes towards ICT as they claim students who use or work on ICT cannot produce a good output, rather, they can engage in some unethical issues and sometime teachers decides to ban their mobile phones (ibid). This brings out the need to create awareness among teachers on the need to understand what ICT tool should be adopted to enhance teaching and learning.

In Tanzania very few educational institutions, mainly private schools in urban areas are using ICT in teaching however, the practices have been limited to basic ICT skills (Maro, 2014). Unsatisfactory integration of ICT in teaching in the country is linked with inadequate ICT facilities. Other factors contributed to this state of affairs include: insufficient ICT infrastructure deployed in teaching and the learning environment, limited ICT competency among teachers and tutors as well as lack of comprehensive ICT training that focuses on effective integration of ICT in teaching and learning (URT, 2015).

Additionally, Andersson, Nfuka, Sumra, Uimonen, and Pain (2014) argue that, there is a low intake of the pedagogical ICT among tutors in teacher training colleges in Tanzania. In this situation there is less preparation of competent ICT teachers who could apply the skills in secondary schools. The ability of teachers to practice pedagogical ICT is highly influenced by the knowledge, competencies, and skills they received during teacher education. However, Ndibalema (2014) reveals that, most secondary school teachers are not aware of the potentials of ICT in their teaching due to insufficient in-service training. Even those who have opportunities to attend the in-service training, the focus has been mainly on basic ICT skills rather than pedagogical skills. Due to low familiarity of ICT as a pedagogical tool, teachers do not integrate it fully in curriculum and assessment rather they use as a presentation package (URT, 2015). In the contemporary classrooms, a teacher should have a wider pedagogical knowledge and skills that facilitate the creation of the right conditions for learning, but this has not been well achieved by secondary school teachers in Tanzania.

Recognizing that teachers need ICT pedagogical skills, the Tanzanian government established the ICT framework for teachers in 2015. The framework outlines ICT Competence Standards for Teachers which defines the competence outcomes and the supporting knowledge and skills that are needed to utilize ICT in performing the job roles related to teaching. It provides the performance indicators to evaluate the level of knowledge and competence of teachers to apply ICT in the educational setting. Specifically, the set of competencies focus on building teacher capacity for mainstreaming ICTs in education, and to support the development of teachers as change agents in the education system (URT, 2015). The need arises since education system faces the pressures and demand of dynamic technological advances in the world.

Despite the initiatives and tremendous increase of the role of ICT in education, Tanzania is facing considerably high resistance from many teachers in using ICT in teaching and learning. This situation has resulted adoption of ICT among individual teachers to remain a critical challenge in secondary schools. Teachers still lack the skills and knowledge needed to be able to teach with ICT successfully. Ngeze (2017) observes that secondary school teachers are ready to use ICT in their teaching and learning activities if and only if they have the skills and knowledge to do so. In the similar way, Kazoka and William (2016) reveals that most secondary school teachers lack proper knowledge of using ICT facilities in teaching and learning process. It suffices to affirm that factors for teachers' adoption of ICT to improve teaching and learning in government owned secondary school in Tanzania has not yet fully explored. This paper, therefore, investigates teachers' competence and associated factors that hinder the adoption with reference to the government secondary school teachers in Hanang district. 


\subsection{Statement of the Problem}

Initiatives such as ICT policy of 2016 in Tanzania aims at accelerating socio-economic development with potentials to transform Tanzania into ICT driven middle-income economy and society (URT, 2016). The policy is formulated within the context of national vision statements guided by the Tanzania Development Vision 2025, which recognizes that ICT is central to a competitive social and economic transformation which calls the need to invest in technology for improving the quality of science-based education and to create a knowledge-based society in general (URT, 2016).

Although different ICT policies and government initiatives are already in place to integrate ICT in the process of teaching and learning, there are still challenges and gaps in incorporating ICT in educational delivery in Tanzania secondary schools. In fact, many educational institutions do not have adequate ICT facilities and bandwidth to meet real demand (URT, 2016). A more difficult question why teachers face some difficulties in adopting the use of ICT in teaching despite the initiatives available? It may be difficult to locate the straight answer to the question, but one logical explanation may be associated with several factors which include lack of adequate computer skills, negative attitudes towards ICT and limited infrastructure (Ndibalema, 2014). In the similar ways, Kayombo (2016) found several gaps which exist between the ICT policy and the real practice or implementation of ICT objectives in education. Among the gaps include limited teachers' awareness and training in ICT integration, and electricity and ICT facilities supply in most schools. Further the findings revealed that half of the surveyed teachers $(50.5 \%)$ in Tanga and Mwanza regions were unable to use computers in preparing their lesson plans. This could mean that ICT integration in teaching and learning in secondary schools is not really promising.

Other possible explanations may be related to the teachers' ICT framework which lacks adequate strategies to prepare teachers to integrate ICT in teaching and learning. What one sees is just a list of ICT skills that should be possessed by the teacher while the means for adoption are not well stipulated. Although the framework is in place still it acknowledges that systems and digital content available are insufficient (URT, 2015). Even the curriculum appears to be silent to a specific use of ICT in accomplishing learning objectives. On this basis, strategies for ICT adoption among secondary school teachers remain unclear. The problem could further be linked to the teacher education programmes. A critical review on bottlenecks in preparation of quality teachers in Tanzania by Kitta and Fussy (2013) indicates that at the University of Dar es Salaam there is a serious shortage, among other things, of space for self-study, an equipped library, computers with internet access and printing and copying facilities. The critical review made by the aforementioned researchers indicates that even educational technology courses offered in teacher education institutions lack appropriate strategies for adopting emerging technological innovations that can support teaching. The question on how a teacher should adopt technology in teaching remains questionable as graduates lack adequate practices on the integration of ICT in teaching. Therefore, the purpose of this paper is to assess teachers' adoption of ICT to improve teaching and learning in government secondary schools in Hanang district. The study provides insights for teachers, educators and school administrators to reflect upon various ways that may help teachers in achieving their academic goals by using ICT in teaching and learning.

\subsection{The Consideration of Marcus's Theoretical Model of Adoption}

Ankem (2004) stresses that Marcus's theoretical model of adoption of technology has been derived from the diffusion of innovation theory and the social learning theory. The model addresses the adoption of innovation on both individual and organizational levels. On the individual level the adoption is based on the availability of necessary resources, the value an individual attaches to the innovation, and the opportunity to learn about the innovation by observing others (Marcus, 1986). While at the organisation level, the adoption is based on institutions' ability to provide the conditions conducive to the introduction and acceptance of technological innovations that could be used to map out an institutional framework for effective adoption (ibid).

Based on Marcus (1986) model, it was expected that most secondary school in Hanang District have access to ICT facilities that motivate them to improve their teaching. It was also assumed that those teachers who are using ICT to enhance their teaching would value and appreciate the opportunities provided by technology. The expectation was that these teachers would mentor other teacher who have not adopted technology yet. Again, it was assumed that school management is providing effective support including school based training and orientation to new technological innovations.

The model therefore, provides a holistic understanding of multiple factors that necessitates effective adoption of ICT to enhance teaching and learning. Apart from the value an individual is likely to attach to the new innovation, the model could go beyond and address other several factors which could be reflected in the following questions: What knowledge needed for proper adoption? What type of technology is needed by the teachers for proper ICT adoption? What pedagogical skills are needed by the teachers for proper ICT adoption? What specific strategies the school management should put in place to support effective adoption? These questions are very important when reflecting the concept ICT adoption in teaching and learning although Marcus Model did not address them straight forward. It is also important for teachers to understand how social change occurs and the role of technology in bringing about competence in teaching and learning by 
using ICT. In this regard, Marcus's Theoretical Model of Adoption provides insights for proper understanding on how new technology could be adopted in teaching and learning.

\subsection{Research Questions}

The study was guided by the following research questions:-

a) What are the Teachers' skills on ICT Integration in Teaching and learning?

b) What are the constraints that hinder teachers' adoption of ICT for teaching and learning?

\section{Research Methodology}

This study was conducted in Hanang district in Manyara region. The study adopted a mixed research approach which comprised of qualitative and quantitative approaches. These approaches enabled the researchers to have a full picture and in depth-information relating to teachers' adoption of ICT in teaching and learning in government owned secondary school. The researchers used both approaches so as to gain a deeper understanding of the problem. Johnson, Onwuegbuzie, and Turner (2007) assert that, the mixed research approach is normally used when the researcher intends to gain a comprehensive understanding of a problem and undertake an in-depth subjective assessment. Qualitative approach allowed the researchers to enter the respondents' personal world in order to gain deeper and clear understanding of their roles, experience, challenges and feelings (Creswell, 2003). On the other hand, quantitative approach helped the researchers to obtain and present data through frequencies and percentages calculated to predict and interpret the respondents' views on the teachers' adoption of ICT. The use of mixed approach helped to strengthen the validity and reliability of the data which was collected. Also, this approach was chosen because of its power to control the technical weaknesses and bias of one approach with the strengths of the other (Creswell, 2003; Greene, 2006).

The target population of the study included District Education Officer (DEO), Quality Assurer, Heads of School and Teachers from government owned secondary school in Hanang District. Simple random sampling was employed in the selection of participants so that, every individual in the target population could have an equal chance of being included in the sample (Omari, 2011). This technique was employed to obtain 15 selected secondary schools and 75 teachers from the respective schools where by 5 teachers were selected from each school.

Interviews and questionnaires were main tools for obtaining relevant information. Semi-structured interview questions were employed in the collection of rich qualitative data due to its flexibility. According to Harrell and Bradley (2009) semi-structured interview allows probing to ensure that information that will not be sufficiently provided in the previous conversation is obtained. The researchers used interview as an interpersonal conversation administered for obtaining relevant in-depth information. Interviews were carried out to the DEOs, Quality Assurers and teachers for in-depth understanding of technical, administrative and policy implementation of teaching using ICT in government secondary schools. Questionnaires were administered to Teachers and Heads of schools in the selected government owned secondary schools. Both open-ended and closed-ended questionnaires were applied. The open-ended questionnaires allowed more freedom of answering questions on teachers' adoption of ICT to improve teaching and learning in secondary schools. Also, the closed-ended questionnaires helped the researchers to get relevant information about teachers' adoption of ICT in teaching and learning. The aim was to observe similarities and differences in the respondents' perspectives on teachers' adoption of ICT in teaching and learning.

The qualitative data which were collected through interviews and open ended questionnaires were subjected to content analysis to make valid inferences from the data. On top of that, the information was presented in the form of quotations obtained from the respondents as interpreted by the researchers. The quantitative data obtained from closed ended questionnaires were analysed by using Statistical Packages for Social Sciences (SPSS) version 21 software to determine the frequency percentages and mean of the extent of teachers' adoption of ICT in teaching and learning in government secondary school.

\section{Results and Discussion}

The results of the study are presented in the light of the research questions as follows;

a) What are the teachers' skills on ICT integration in teaching and learning?

This research question sought to examine the teachers' skills in using ICT to improve teaching and learning in government owned secondary schools in Hanang district. Data on this question were collected through questionnaire and interviews as presented in Table 1 next. 
Table-1. Frequency, Percentage and Mean Distribution of Teachers'skills on ICT Integration in Teaching and learning (N=75).

\begin{tabular}{|c|c|c|c|c|c|c|c|c|c|c|}
\hline \multirow[b]{2}{*}{$\mathbf{S} / \mathbf{N}$} & \multirow{2}{*}{$\begin{array}{l}\text { Teachers' skills in Using ICT for } \\
\text { Teaching and Learning }\end{array}$} & \multicolumn{2}{|c|}{$\mathbf{S A}$} & \multicolumn{2}{|c|}{ A } & \multicolumn{2}{|c|}{ D } & \multicolumn{2}{|c|}{ SD } & \multirow[t]{2}{*}{ MEAN } \\
\hline & & $\mathbf{F q}$ & $\%$ & $\mathbf{F q}$ & $\%$ & $\mathbf{F q}$ & $\%$ & $\mathbf{F q}$ & $\%$ & \\
\hline 1 & $\begin{array}{l}\text { I can use ICT to prepare my scheme of } \\
\text { work and lesson plan. }\end{array}$ & 1 & 1.3 & 9 & 12.0 & 59 & 78.7 & 6 & 8.0 & 2.07 \\
\hline 2 & $\begin{array}{l}\text { I am able to identify ICT tools and } \\
\text { digital content that can support } \\
\text { students' learning. }\end{array}$ & $\mathrm{O}$ & $\mathrm{O}$ & 7 & 9.3 & 63 & 84.0 & 5 & 6.7 & 2.07 \\
\hline 3 & $\begin{array}{l}\text { I can manage to identify and manage } \\
\text { internet safety issues. }\end{array}$ & 1 & 1.3 & 6 & 8.0 & 65 & 86.7 & 3 & 4.0 & 2.07 \\
\hline 4 & $\begin{array}{l}\text { I have attained sufficient knowledge to } \\
\text { integrate ICT in teaching }\end{array}$ & $\mathrm{O}$ & $\mathrm{O}$ & 7 & 9.3 & 65 & 86.7 & 3 & 4.0 & 2.07 \\
\hline 5 & $\begin{array}{l}\text { I have an ability to select, describe and } \\
\text { use ICT facilities to support my } \\
\text { teaching }\end{array}$ & $\mathrm{O}$ & $\mathrm{O}$ & 9 & 12.0 & 62 & 82.7 & 4 & 5.3 & 2.05 \\
\hline 6 & $\begin{array}{l}\text { I can manage to build up my teaching } \\
\text { through power point presentation to } \\
\text { convey my lesson. }\end{array}$ & $\mathrm{O}$ & $\mathrm{O}$ & 10 & 13.3 & 53 & 70.7 & 12 & 16.0 & 2.05 \\
\hline 7 & $\begin{array}{l}\text { I have ability to use Search Engines } \\
\text { such as Google to find relevant } \\
\text { materials for my students }\end{array}$ & 19 & 25.3 & 51 & 68.0 & 5 & 6.7 & $\mathrm{O}$ & $\mathrm{O}$ & 3.19 \\
\hline 8 & $\begin{array}{l}\text { I am able to record my teaching notes } \\
\text { on storage devices and use them in my } \\
\text { lesson. }\end{array}$ & 1 & 1.3 & 2 & 2.7 & 55 & 73.3 & 17 & 22.7 & 2.05 \\
\hline 9 & $\begin{array}{l}\text { I can use ICT knowledge and skills I got } \\
\text { from college to contribute my daily } \\
\text { teaching activities. }\end{array}$ & $\mathrm{O}$ & $\mathrm{O}$ & 8 & 10.7 & 63 & 84.0 & 4 & 5.3 & 1.97 \\
\hline 10 & $\begin{array}{l}\text { I am able to use ICT to access digital } \\
\text { resources to support my own } \\
\text { professional learning }\end{array}$ & $\mathrm{O}$ & $\mathrm{O}$ & 7 & 9.3 & 65 & 86.7 & 3 & 4.0 & 1.83 \\
\hline
\end{tabular}

The results summarized in Table 1 shows that 9 out of 10 responses fall under the "disagree" category (1.5-2.4), while 1 response under "agree" category (2.5-3.4). The logical interpretation is that teachers' skills in using ICT for teaching and learning was low. The findings also revealed that, most of the government secondary school teachers were not competent enough to integrate ICT in the process of teaching and learning. Although one statement "I have an ability to use search engines such as Google to find relevant materials for my students" (3.19), has been ranked the highest, still the majority appeared to lack appropriate skills of using ICT in teaching and learning. Therefore, the findings proved that, most of the secondary school teachers were lacking adequate skills in using ICT in teaching and learning in secondary schools.

Teachers' skills in using ICT in teaching and learning was also investigated through interviews with DEOs and Quality Assurers. Their comments appear to complement the results in Table 1 of which they agreed that the majority of teachers are not competent to use ICT in teaching and learning process. One DEO was quoted saying:

"...Despite the little knowledge they have on internet use, most teachers are not using the internet for academic purposes, but they use it for their personal issues and communicate with their friends, so they need more training to integrate ICT in teaching and learning..." (DEO; February 2017).

From the quote above, it seems that, most of the teachers were not using the internet for academic issues, but they use it for their personal issues such as charting and sending different documents. It makes sense to argue that teachers lacked a clear vision and understanding on what the internet can do in enhancing their professional learning and teaching practices. One would suggest the need of the training to expose them on the value of the internet in supporting teaching and learning. Some supportive data from the quality assurer revealed the similar challenge regarding teachers' competence as a result of lack of training opportunities. The quality assurer responded this:

"...Most of the teachers in this district do not have adequate skills and knowledge of using ICT in teaching and learning that can enable them effectively integrate it in the process of teaching and learning. One of the challenges is lack of opportunities for training. As you know, there are many technological opportunities today, but still our teachers lack exposure to them through training. It is possible to plan and invite experts for the task but resources are not enough. Some teachers with skills may have acquired them through personal struggles ...” (QA 2; February, 2017). 
From the above response, it can be proved that, lack of well trained teachers in ICT application has been recognized as the major obstacle in the adoption of ICT in secondary schools to improve teaching and learning.

Another Quality Assurer added that:-

"...I believe that, Teachers are the major agents in the use of ICT though, during my inspection sessions in secondary school, most are found to have a negative attitude towards the use of ICT as a tool for enhancing teaching and learning. School heads school heads have not been doing the needful to encourage their teachers on the matter. Still, we have a lot to do to change the teacher's mindset on the use of ICT..." (QA 1; February 2017).

The quote above shows that, although the teachers' attitude towards the use of ICT is vital, some of them are sceptical in accepting the new innovations. Having a negative attitude on the use of ICT could be linked with lack of awareness on ICT opportunities and fear to try out the new innovations in teaching. Responses from the quality assurer revealed that some teachers lack mentors who are skilled in ICT and the school leadership has not been fairly encouraging them. This could be one of the reasons to which ICT adoption is very minimal. The availability of qualified teachers with ICT skills could inspire others to adopt the same, but this has not been happening. Most schools did not have enough teaching staffs who are competent in using ICT for enhancing teaching and inspire other teachers who have not adopted yet. One female Quality Assurer had this to say:-

"...Limited number of teachers who are qualified in ICT use is one of the challenges in many secondary schools. The majority of teachers in government owned secondary schools in Tanzania have no skills and competencies needed in integrating ICT in schools...” (QA 3; February 2017).

The quotation above shows that, in many governments owned secondary schools in Tanzania there is a limited number of qualified teachers who are competent in using ICT in teaching and learning. On the same matter, one quality assurer added that:

"... There are some secondary school teachers who know less about the use of ICT in teaching and learning and they don't want to learn from the colleagues. Some teachers are not even ready to change the pedagogical techniques of teaching, but the problem; there is no one who takes the trouble to try the new ICT based strategies..." (QA 3; February 2017).

In the same way, the above quote shows that, most of the secondary school teachers know a little about the use of ICT in teaching and learning and still embrace the conventional pedagogical techniques of teaching. Based on the findings above, it could be argued that teachers are supposed to adopt new technology in their teaching as things keep on changing. Failure to adopt ICT among teachers, calls for the need to arouse the required pedagogical skills among teachers. In this digital world, we expect teachers being competent in various ICT pedagogical strategies in order to help their students improve their learning.

Additionally, one of the teachers in one school lamented that:-

"...I am very eager to understand and be competent in the use of ICT in my daily professional activities, but the problem is lack of ICT facilities in schools, electricity and lack of internet connection. I suggest the government has to put more effort to supply ICT facilities in schools because it could help us to become competent to use computers though the majority of us are living in rural areas..." (Teacher from School 1; February 2017).

The above quote proves that, most of the teachers are not competent to use ICT in teaching and learning because of lack of exposure to digital materials and facilities. The researchers are of the view that, if they are provided with the ICT facilities and opportunity for ICT training, it is possible to witness the effective adoption. Teachers' adoption of ICT to improve teaching and learning in government owned secondary school has been very minimal due to several factors which include lack of competence, exposure, facilities, training and mentors, just to mention a few.

The findings in the preceding discussion are consistent with the study by Ngeze (2017) who found that teachers are ready to apply the ICT skills to improve their teaching and learning experience if they are exposed to training. The study further reveals that most of the secondary school teachers in the study area $(77.0 \%)$ now possess either a laptop or a smartphone or both. It has been a common practice for teachers to possess those facilities like smartphone but still the lack adequate knowledge on how they can be used to support teaching. It has been also mentioned that teachers lack mentorship from school leadership or fellow teachers with ICT expertise. In order to achieve the effective adoption of ICT in enhancing teaching and learning school leadership has to collaborate and create a positive relationship towards a shared vision and interest. When teachers have an opportunity to learn from each other, majority are likely to acquire relevant ICT pedagogical skills. This is in line with the findings by Ndibalema (2015) who revealed that collaboration creates various opportunities where teachers may be more flexible to advance their professional growth through ICT.

Elsewhere, it has been found that there are similar challenges facing teachers in adoption of ICT in teaching and learning. The study carried out by Omoniyi and Quadri (2003) on perceived competence of Nigerian secondary school teachers in the use of ICT revealed that, majority of teachers in secondary schools do not have the required competence in the use of ICT. Key factors addressed to contribute to the matter 
include lack of expertise, lack of knowledge on how to evaluate the use and role played by ICT in the teaching and learning and insufficient knowledge of appropriate software as factor hindering the readiness of using ICT. Similarly, Mingaine (2013) investigated the challenges in the implementation of ICT in public secondary Schools in Kenya and observed that, there are limited resources to equip schools with ICT infrastructure and this has been a barrier in implementation of ICT to support curriculum delivery. Even the Standard software for use in schools for learning and administration are not widely available. Unfortunately, in many African countries, lack of well trained teachers and low levels of teachers' ICT skill and knowledge has been recognized as major obstacle in implementation of ICT in schools (Dzidonu, 2010). In Tanzania, poor adoption of ICT has also been equated to teacher education programmes. The review of teacher education curriculum indicate that teachers' training programmes particularly in computer and other multi-media utilization are ineffective which has been identified as a major reason for slow take-up of ICT in education (URT, 2016). If the programmes are insufficient, it is possible for teachers graduating from the colleges to have minimal ICT skills. Programmes might be available but lacking real ICT pedagogical practices which actually model teachers' competence, limits the acquisition of the required ICT competencies.

However, the findings of the present study are contrary to the study conducted by Gharisekr et al. (2013) on ICT Integration in education in teaching and learning improvement. It was found that most of the teachers in the Klang Valley Malaysia are more likely to use ICT applications and resources for educational purposes, such as the internet, multimedia computer, projector system, power point presentation, or word processor programs during the teaching and learning process. The study further addresses that to ensure successful ICT integration in secondary schools, scholars have to emphasize about how teachers integrate ICT into the teaching and learning process. Similarly, a study by Ghavifekr, Kunjappan, Ramasamy, and Anthony (2016) on teaching and learning with ICT Tools, revealed that, many teachers have competence and confidence in using computers in the classroom. However, they still make little use of technologies because they lack the time. Although the time factor was not one of the aspect assessed in the present study, many scholars agree that it limits teachers on ICT adoption. Lack of time is a universal problem in using technology; it is found wherever using technology is mentioned no matter how developed is the country or not (Al Mulhim, 2014). Time factor may even limit teachers' participation in ICT based professional development for teachers. In order to meet the $21^{\text {st }}$ century learning needs teachers should be dedicated towards the acquisition of ICT pedagogical skills rather than complaining about time in most cases. Teachers' success today, depends on the level of technological skills he or she possesses and they should not be isolated from the information society.

Table-2. Frequency, Percentage and Mean Distribution of the Constraints that Hinder Teachers' Adoption of ICT for Teaching and Learning $(\mathrm{N}=75)$.

\begin{tabular}{|c|c|c|c|c|c|c|c|c|c|c|}
\hline \multirow[b]{2}{*}{$\mathrm{S} / \mathrm{N}$} & \multirow{2}{*}{$\begin{array}{l}\text { Constraints Hindering Teachers' } \\
\text { Adoption of ICT for Teaching and } \\
\text { Learning }\end{array}$} & \multicolumn{2}{|c|}{$\mathbf{S A}$} & \multicolumn{2}{|l|}{$\mathbf{A}$} & \multicolumn{2}{|l|}{$\mathbf{D}$} & SD & \multicolumn{2}{|c|}{ MEAN } \\
\hline & & $\mathbf{F q}$ & $\%$ & $\mathbf{F q}$ & $\%$ & $\mathbf{F q}$ & $\%$ & $\mathbf{F q}$ & $\%$ & \\
\hline 1 & Lack of technical support for teachers & 20 & 26.7 & 51 & 68.0 & 4 & 5.3 & - & - & 3.21 \\
\hline 2 & $\begin{array}{l}\text { Insufficient pre-service and in-service } \\
\text { teacher training }\end{array}$ & 22 & 29.3 & 52 & 69.3 & 1 & 1.3 & - & - & 3.28 \\
\hline 3 & $\begin{array}{l}\text { Fear to use ICT in the classroom } \\
\text { because some students know to use } \\
\text { ICT better than them }\end{array}$ & 2 & 2.7 & 11 & 14.7 & 52 & 69.3 & 10 & 13.3 & 2.07 \\
\hline 4 & $\begin{array}{l}\text { Teachers' unwillingness in accepting } \\
\text { the technological changes }\end{array}$ & 10 & 13.3 & 59 & 78.7 & 4 & 5.3 & 2 & 2.7 & 3.03 \\
\hline 5 & $\begin{array}{l}\text { Limited time to prepare multimedia } \\
\text { lessons }\end{array}$ & 8 & 10.7 & 61 & 81.3 & 6 & 8.0 & - & - & 3.03 \\
\hline 6 & $\begin{array}{l}\text { Lack of management willingness to } \\
\text { support ICT integration }\end{array}$ & 12 & 16.0 & 61 & 81.3 & 2 & 2.7 & - & - & 3.13 \\
\hline 7 & $\begin{array}{l}\text { Lack of collaboration with other } \\
\text { teachers to integrate ICT in teaching }\end{array}$ & 13 & 17.3 & 59 & 78.7 & 3 & 4.0 & - & - & 3.13 \\
\hline 8 & $\begin{array}{l}\text { Lack of skills to connect ICT devices in } \\
\text { the classroom during teaching }\end{array}$ & 8 & 10.7 & 65 & 86.7 & 2 & 2.7 & - & - & 3.04 \\
\hline 9 & $\begin{array}{l}\text { Lack of skills to select, describe and use } \\
\text { various internet services }\end{array}$ & 5 & 6.7 & 68 & 90.7 & 2 & 2.7 & - & - & 3.08 \\
\hline 10 & $\begin{array}{l}\text { Lack of skills to identify ICT tools and } \\
\text { digital content to support my teaching }\end{array}$ & 10 & 13.3 & 63 & 84.0 & 2 & 2.7 & - & - & 3.11 \\
\hline
\end{tabular}

Important note to the findings of the present study is that, teachers play the key role in classroom change and tend to accept changes that they perceive to facilitate their work. Teachers, individually and collectively, have the capacity and the responsibility to influence the development, modification, adoption, and rejection of 
newer technologies. In order to make these critical decisions, they need to understand not only how to use these technologies, but also the benefits and the use of ICT in teaching, learning and managing educational institutions, just like any other innovation. Based on the above findings, it makes sense to conclude that, there was low level of technological awareness and skills in supporting the curriculum implementation as well as professional development. Similarly, lack of clear policy and vision, hardware and software knowledge and unavailability of infrastructure are some of the obstacles to teacher's incompetence for the implementation of ICT in teaching and learning activities in secondary schools.

b. What are the constraints that hinder teachers' adoption of ICT in teaching and learning?

This research question sought to examine the constraints that hinder teachers' adoption of ICT for teaching and learning in secondary school in Hanang district. Data for this question were collected through questionnaires and interviews. Table 2 presents the results.

The results summarized in Table 2 show that, out of 10 statements exposed to the respondents, 9 responses fall under the "agree" category (2.5-3.4), 1 response fall under the "disagree" category (1.5-2.4). None of the responses fall under "strongly disagree" (1-1.4). The findings prove that there is a persistence of many constraints that hinder ICT adoption among secondary teachers in teaching and learning. For instance, out of 10 statements rated, the highest mean score is on "Insufficient of pre-service and in-service teacher training" (3.28), followed by "Lack of technical support" (3.21). It is worthy to mention that lack of effective training and technical support are most pressing issues that limit proper adoption and integration of ICT in teaching and learning. In todays' classrooms, teachers need a deep understanding of ICT integration and, if they do not have it, they need to be given opportunities to learn so that they can cope with the new innovations.

During the interviews with the informants it was revealed that, there are limited resources to equip schools with ICT infrastructure which has been also the barrier in ICT adoption and integration in teaching and learning. Most of schools did not have enough ICT facilities which can be used to support teaching and learning. For instance DEO had this to say:-

"... Most challenging condition to implement ICT strategies in secondary schools is shortage of ICT infrastructure. Moreover, these schools, which have computers, experience limited access to internet connections..." (DEO; February 2017).

The DEO's quote above addresses the need for proper investment in ICT facilities and internet connectivity if we need a proper adoption. Most of the respondents were aware with the potential opportunities provided by ICT in enhancing teaching and learning but lack of effective investment in government owned secondary schools suppresses their efforts to integrate ICT in teaching and learning.

Additionally, poor adoption of ICT in teaching and learning was related to insufficient ICT facilities. For a better understanding, let us consider a few quotes from heads of schools. One head of the school said that:-

"...In my school, there is insufficient ICT facilities and the way classrooms are constructed it is impossible to install them. As you can see even the accessibility of electricity is still a big challenge. I really don't have proper words to say but ICT integration is less possible for the time being in our school..." (HoS 1; March 2017).

One important message from the above quote is the issue of teaching and learning environment. With limited resources, it is possible for school teachers be affected with the situation and thus low uptake on the integration of ICT in teaching and learning. Another Head of School added that:-

"...My teachers are not using ICT in teaching and learning though there are few ICT facilities and electricity. The major problem is lack of pedagogical skills regarding to what lesson should be taught by using ICT..." (HoS 2; March 2017).

Although HoS2 is shifting from the idea of physical resources as a challenge for ICT adoption, still he mentions lack of ICT pedagogical skills as a main constraint among teachers in that school. The logical implication could be that, having ICT facilities is not a guarantee for effective adoption. The school may have adequate facilities but if teachers lack interest and skills to use them, adoption will be difficult. On the same matter, another Head of School added that:-

“...We lack adequate resources from the government, we possess many computers which are not working, we also lack competent teachers who can use ICT effectively in teaching and learning are the major challenges which make the adoption of ICT to teachers in teaching and learning to become very minimal..." (HoS 3; March 2017).

From the above quote, it is evident that, there is a challenge of many schools to possess computers which are not functioning. However, there were no clear mechanism for maintenance due to insufficient funds and technical support. On this basis, teachers' adoption of ICT in teaching and learning remains to be a challenge. Again, lack of training was a challenge mentioned by many teachers as one of them affirmed that:-

"... The government should provide the training on the computer skills to us so as to make us to be up to date... this will help us to cope with the world of globalization and new innovations. To me, lack of in-service training and insufficient technological infrastructures seem to be the factors that have a significant influence on the effective use of technology by us teachers..." (Teacher from School 5; February 2017). 
The findings above prove that, there is a challenge of lack of in-service training for teachers and insufficient technological infrastructures. Although in some schools the ICT facilities were available but they were insufficient. In most interviewed teachers, it was mentioned that ICT facilities were available, but lacked pedagogical skills due to limited exposure and mentorship on the use of ICT facilities. Lack of in-service training has also been mentioned as a factor, due to the fact that the opportunities are limited. The matter may be extended to the pre-service programmes in teacher education colleges which seem to be insufficient in providing relevant ICT pedagogical skills. One would expect a teacher graduating from teacher Education College with basic ICT skills but, this was not actually happening to most teachers in schools under investigation.

In view of these arguments, it is obvious that the respondents faced many challenges on using ICT in teaching and learning. Yet, lack of ICT infrastructure, lack of human skills and knowledge to fully integrate ICT into teaching and learning were found to be the major challenges. However, most secondary school teachers lack the skills to fully utilize technology in curriculum implementation hence the conventional chalk and talk approach still dominates teaching in secondary school classrooms.

The study found that majority of the teachers involved in the study have low level of knowledge and skills about ICT in teaching and learning. This may imply that the teachers are not actually competent in using ICT though some have little knowledge of ICT use which they gained from colleges. Further, the findings from the classroom observations revealed many challenges faced by the teachers in using ICT in teaching and learning in secondary schools. Some of the challenges include lack of ability to select, describe and use various internet services. Again, teachers lacked ability to connect ICT devices in the classroom during teaching process and were unable to identify ICT tools and digital content that can support learning environments for enabling learner's understanding of key subject-specific concepts. Additionally, the findings revealed that, in schools that had computers, some were not functioning. This is in line with the Basic Education Statistics across all regions in Tanzania which indicate that number of ICT equipment (Desktop and laptop computers) available in government owned secondary schools is 10449 while in Hanang District only 244 desktop and laptop computers are available (URT, 2017). Further statistics indicate that in Hanang District there are 33 government owned secondary schools with a total enrolment of 8087 students (URT, 2017). One may question the ratio of students and the available ICT equipment, does it match with the learning needs? While the latest ICT national policy in Tanzania stresses the need to develop and enhance human capital that is capable of championing ICT in the creation of Tanzania's knowledge society (URT, 2016), the ICT infrastructure to bridge the digital divide that exist among students is still very minimal.

The findings regarding the constraints on lack of adequate facilities corroborate with the study findings by Kafyulilo (2014) who found that most of the secondary schools in Tanzania experience inadequate resources of ICT from the government. Some secondary schools have computers which are not working while other schools have computers only for administrative purposes. There are also schools which do not have even a single computer or a radio or a TV for teaching and learning process. An absence of electricity in some schools is a big challenge (Ibid). It is very difficult to operate ICT equipment and Internet to a school where there is no electricity. Consider an example of Hanang District, out of 36 government and non-government secondary schools only 18 schools have access to National grid electrical power, 10 have access to solar power while 8 schools have no access to any source of power (URT, 2017). Based on the interview with some heads of schools, it was also revealed that even in schools with electricity, sometimes the payment of electricity bills is a problem although the government brings the capitation grants on time but not sufficient. In view of the preceding challenges, it could be logical to note that lack of readiness among teachers to adopt ICT in teaching may have been influenced with lack of reliable source of power.

Again, drawing from the study by Kafyulilo (2014), many teachers in secondary schools in Tanzania decide not to use ICT in teaching and learning due to lack of facilities and high expenses of internet bandwidth. It has been acknowledged in the Tanzanian ICT competency Framework for teachers of 2015 that, ICT integration in teaching and learning in Tanzanian schools is still at its infancy stage. Among the challenges highlighted in the framework which seem to influence poor adoption of ICT include obsolete ICT infrastructure deployed in teaching and the learning environment, limited ICT competency among teachers and tutors as well as a lack of comprehensive ICT training on effective integration of ICT in teaching and learning (URT, 2015). It can be said that effective integration of ICT in teaching needs a strong infrastructure and clear strategies to achieve the intended educational goals. For instance, in the vision 2025 it has been stressed that there is a need of adequate investments ICT to improve the quality of science based education so as to create a knowledge society generally. It is difficult to achieve this if there is no clear link between instituted ICT strategies and learning goals. When institutionalising the integration of ICT in teaching and learning, several questions need to be addressed in the policy implementation strategies. The questions may include: How ICT relates with the learning objectives? How ICT is appropriate to the learning tasks? How ICT is coherent to the pedagogy? How ICT is coherent to the content? How can it be used to assess students' learning? Does it match with students learning styles? Integration of ICT is not just the matter of availability of facilities but it needs a deeper personal understanding of instructional strategies which can facilitate the effective adoption. 
Based on the findings by Kayombo (2016) there are still several gaps that need to be addressed for effective integration of ICT in teaching and learning in secondary schools in Tanzania. He addresses that there is a mismatch between the ICT policy and the real practice or implementation of ICT objectives in education in several ways: First, many teachers are not aware of the existing policy and in case of the integration they are not prepared too. The skills needed by the teacher in the technological classroom is addressed in the ICT competence framework for teachers. Some critical forward looking reflection could be made on the matter. The framework stresses that teachers need technological literacy of which they should be aware with education and training policy and articulate in consciously skilled ways how usages of ICT corresponds to and support the policy (URT, 2015). One would ask: how many teachers have access to education policy and can analyse it into achievable practices by making logical interpretation in relevancy to ICT pedagogical skills? This is in line with the second issue addressed by Kayombo (2016) that teachers' training in ICT knowledge and skills were not made in accordance with the requirement of the ICT policy objectives. It could be said that it is very difficult to put the ICT policy objectives into practice if the training strategies for teachers are not clear. Again, the ICT competence framework for teachers stresses that teachers should possess the technological skills and knowledge of web resources necessary to acquire additional subject matter and pedagogical knowledge in support their own professional development (URT, 2015). One would also question: how many teachers are aware that web-based resources can be used for professional learning? What is the motivation behind if the teacher cannot access ICT facilities and internet at school? How professional learning through web-based resources can happen without internet access? The logical implication on the above questions, is that, if we want to bridge the digital divide by harnessing the learning opportunities for teachers through ICT, strong investments is inevitable.

Based on the number of available ICT facilities in government owned schools as it has been addressed in the preceding discussion, the gap between those teachers who can access the digital information and who are not is still high. This creates the digital divide which has been considered to be the major factor that affect opportunities for teachers to integrate ICT in their teaching. The digital divide affects teachers who cannot access the internet in their work environment. Basic Education Statistics in Tanzania provides the statistics regarding the number of computers and other technological devices, but the issue on how many educational institution are connected with the internet is not well known. Basically, in the visited schools there were no even a single school with internet connectivity but some teachers use their personal modems for connectivity of which they claimed to be expensive.

In a broader sense, the findings of the present study have highlighted the limited access of ICT hardware and software, to support effective teaching and learning using ICT in Tanzanian secondary schools. The findings also revealed that, the difficulty in integration of ICT in teaching and learning is due to a number of constraints such as insufficient funding on ICT facilities, lack of clear ICT strategies, poor electricity supply, lack of competent ICT teaching staff, just to mention a few. If we are to build the information society, it is our obligation to ensure that both teachers and students are exposed to technological learning environment for them to come up with new innovations and discoveries. Adoption of ICT in teaching and learning may be enhanced depending on the multiple factors which may include accessibility of ICT facilities, personal readiness, training and supply of reliable electricity in schools. Having such support, would help to bridge the digital divide as a ladder for effective adoption and integration of ICT in teaching and learning.

\section{Conclusion and Recommendations}

This study has addressed that teachers had low level of ICT awareness and skills in supporting the curriculum implementation as well as professional development. Effective adoption of ICT among teachers to improve teaching and learning in government owned secondary schools in Tanzania depends on teachers' level of understanding and competence in utilizing fully the technological devices. Many teachers were found to lack adequate pedagogical skills in using technological devices to enhance their teaching. However, many teachers highlighted the need training influence that could influence their readiness in teaching by using technological devices. Teachers should be convinced to realise the usefulness and benefits of technological devices in improving teaching and learning and their professional growth. This study therefore, suggests the need for effective investment in ICT facilities, strong mentorship, technical support and training. As we speak today, there are many new innovations which include learning portals and digital content that can support teaching across different disciplines. On this basis, teachers can be supported to improve their ICT pedagogical practices through the learning management systems that allow flexibility in learning at their own pace and time. There has been also a number of new social networks which can be explored to and be used to create awareness among teachers on how ICT can be adopted and integrated in teaching and learning. This would provide new possibilities for learning new strategies and sharing of the digital content that can foster teaching and learning.

It is possible if teachers have reliable access to internet in their working environment, they may engage in online professional development opportunities. This study therefore, suggests that teachers need to be involved in continuous professional learning and training on the use of ICT. And this exercise of teaching should be a routine exercise in all schools if we want to achieve the state vision 2025 of creating the 
information society. Again, a critical review of Teacher education programmes is needed of which ICT as pedagogical tool should be one of the mission in all teacher education programmes. Although ICT competence standards for teachers exists in Tanzania, still the holistic approach should be adopted to ensure what is stated matches with teachers beliefs and classroom practices. The technological literacy and deepening knowledge skills addressed in the framework should be part of the teacher education curriculum. On this basis, a clear harmonisation among institutions offering teacher education programmes and policy makers should be in place. A critical attention on policy strategies on how a teacher should integrate ICT in the school curriculum should be in place and this should go in hand with the availability of ICT facilities in schools.

\section{Acknowledgement}

Our sincere thanks go to all our respondents whose views and experiences have invaluably contributed to the success of this study. Their valuable time and readiness during the field work remain to be strongly appreciated.

\section{References}

Adelabu, O., \& Adu, E. O. (2015). Information and communication technologies (ICT) facilities for effective instructional delivery in tertiary institutions. Journal of Communications, 6(1), 182-187.

Al Mulhim, E. (2014). The barriers to the use of ICT in TEACHING In Saudi Arabia: A review of literature. Universal Journal of Educational Research, 2(6), 487-493.

Andersson, B., Nfuka, E. N., Sumra, S., Uimonen, P., \& Pain, A. (2014). Evaluation of implementation of ICT in teachers' colleges project in Tanzania. Final Evaluation Report No. Sida61745en urn:nbn:se:sida-61745en. Stockholm, Sweden: Swedish International Development Cooperation Agency (SIDA).

Ankem, K. (2004). Adoption of internet resource-based value-added processes by faculty in LIS education. Library and Information Science Research, 26(4), 482-500.

Cakir, R., \& Yildirim, S. (2013). ICT teachers' professional growth viewed in terms of perceptions about teaching and competencies. Journal of Information Technology Education: Innovations in Practice, 12(unknown, 221-237.

Copriady, J. (2015). Self-Motivation as a mediator for teachers in applying ICT in teaching and learning. Faculty of Education, University of Riau Indonesia. Procedia-Social and Behavioral Sciences, 176(5), 699-708.

Creswell, J. (2003). Research design qualitative, quantitative, and mixed methods approaches. Thousand Oaks: CA: Sage Publications.

Dzidonu, C. (2010). The role of ICTs to achieving the MDGs in education: An analysis of the case of African countries. The Division for Public Administration and Development Management of the United Nations Department of Economic and Social Affairs (UNDESA).

Felvégi, E., \& Matthew, K. I. (2012). Books and literacy in K-12 Schools. Computers in the Schools, 29(1-2), 40-52.

Gharisekr, S., Razak, A. A. Z., Ghan, A. M. F., Ran, Y. N., Meixi, Y., \& Tengyue, Z. (2013). ICT integration in education: Incorporation for teaching and learning improvement. The Malaysian Online Journal of Educational Technology, 2(2), 24-45.

Ghavifekr, S., Kunjappan, T., Ramasamy, L., \& Anthony, A. (2016). Teaching and learning with ICT tools: Issues and challenges from teachers' perceptions. Malaysian Online Journal of Educational Technology, 4(2), 38-58.

Greene, J. C. (2006). Toward a methodology of mixed methods social inquiry. Research in the Schools, 13(1), 93-98.

Harrell, C. M., \& Bradley, M. (2009). Data collection methods: Semi-structured interviews and focus groups. Virginia: RAND Publisher

Johnson, R. B., Onwuegbuzie, A. J., \& Turner, L. A. (2007). Toward a definition of mixed methods research. Journal of Mixed Methods Research, 1(2), 112-133.

Kafyulilo, A. (2014). Access, use and perceptions of teachers and students towards mobile phones as a tool for teaching and learning in Tanzania. Education and Information Technologies, 19(1), 115-127.

Kayombo, J. J. (2016). The paradox of ICT integration in secondary education in Tanzania: Assessment of teachers ICT knowledge and skills in Tanga and Mwanza Region. International Journal of Research Studies in Educational Technology, 5(1), 17-27.

Kazoka, R., \& William, F. (2016). Secondary school teachers' knowledge and practice towards the use of ICT. Merit Research Journal of Education and Review, 4(2), 14-18.

Kitta, S., \& Fussy, D. (2013). Bottlenecks in preparation of quality teachers in Tanzania. Time Journals of Arts and Educational Research, 1(5), 29-38.

Marcus, J. (1986). Diffusion of innovations and social learning theory: Adoption of the context text-processing system at Stanford University. Doctoral Dissertation, Stanford University.

Maro, N. (2014). The use of computers in public and private primary schools in Tanzania: A digital divide. International Journal of Computer Applications, 103(15), 14-19.

Mingaine, L. (2013). Challenges in the implementation of ICT in public secondary schools in Kenya. International Journal Social Science E Education, 4(1), 227-393.

Ndibalema, P. (2014). Teachers' attitudes towards the use of information communication technology (ICT) as a pedagogical tool in secondary schools in Tanzania: The Case of Kondoa district. International Journal of Education and Research, 2(2), 1-16.

Ndibalema, P. (2015). Transforming teachers' professional competence in the use (ICT) as a pedagogical tool: An experience of community of practice learning model in secondary schools in Tanzania. Unpublished Research Thesis Submitted in Fulfilment of the Requirements for Degree of Doctor of Philosophy of the University of Dodoma.

Ngeze, L. (2017). ICT integration in teaching and learning in secondary schools in Tanzania: Readiness and way forward. International Journal of Information and Education Technology, 7(6), 424-427. 
Omari, I. M. (2011). Concept and methods in education research. Dar es Salaam: Sage Publication.

Omoniyi, T., \& Quadri, A. T. (2003). Perceived competence of Nigerian secondary school teachers in the use of information and communication technology (ICT). Journal of Education and Practice, 4(10), $157-164$.

Raman, K., \& Yamat, H. (2013). Barriers teachers face in integrating ICT during English lesson. The Malaysian Online Journal of Educational Technology, 2(3), 11-19.

Salisu, I., \& Muhammad, Y. M. (2016). Problems preventing the educators/instructors to employ ICT in teaching and learning process in Nigeria. Department of computer science, Shehu Shagari College of Education, Sokoto. Journal of Educational Policy and Entrepreneurial Research, 3(7), 89-94.

URT. (2015). ICT competency standards for teachers in Tanzania. Dar es Salaam: The Government Printer.

URT. (2016). National information and communications technology policy. Dar es Salaam: The Government Printer.

URT. (2017). Basic education statistics in Tanzania. Dar es Salaam: The Government Printer. 